This item was submitted to Loughborough's Research Repository by the author.

Items in Figshare are protected by copyright, with all rights reserved, unless otherwise indicated.

\title{
Prevention through design: The effect of European Directives on construction workplace accidents
}

PLEASE CITE THE PUBLISHED VERSION

PUBLISHER

(C) Elsevier

VERSION

AM (Accepted Manuscript)

LICENCE

CC BY-NC-ND 4.0

\section{REPOSITORY RECORD}

Aires, M.D. Martinez, M.C. Rubio Gamez, and Alistair G.F. Gibb. 2019. "Prevention Through Design: The Effect of European Directives on Construction Workplace Accidents". figshare. https://hdl.handle.net/2134/6245. 
This item was submitted to Loughborough's Institutional Repository (https://dspace.lboro.ac.uk/) by the author and is made available under the following Creative Commons Licence conditions.

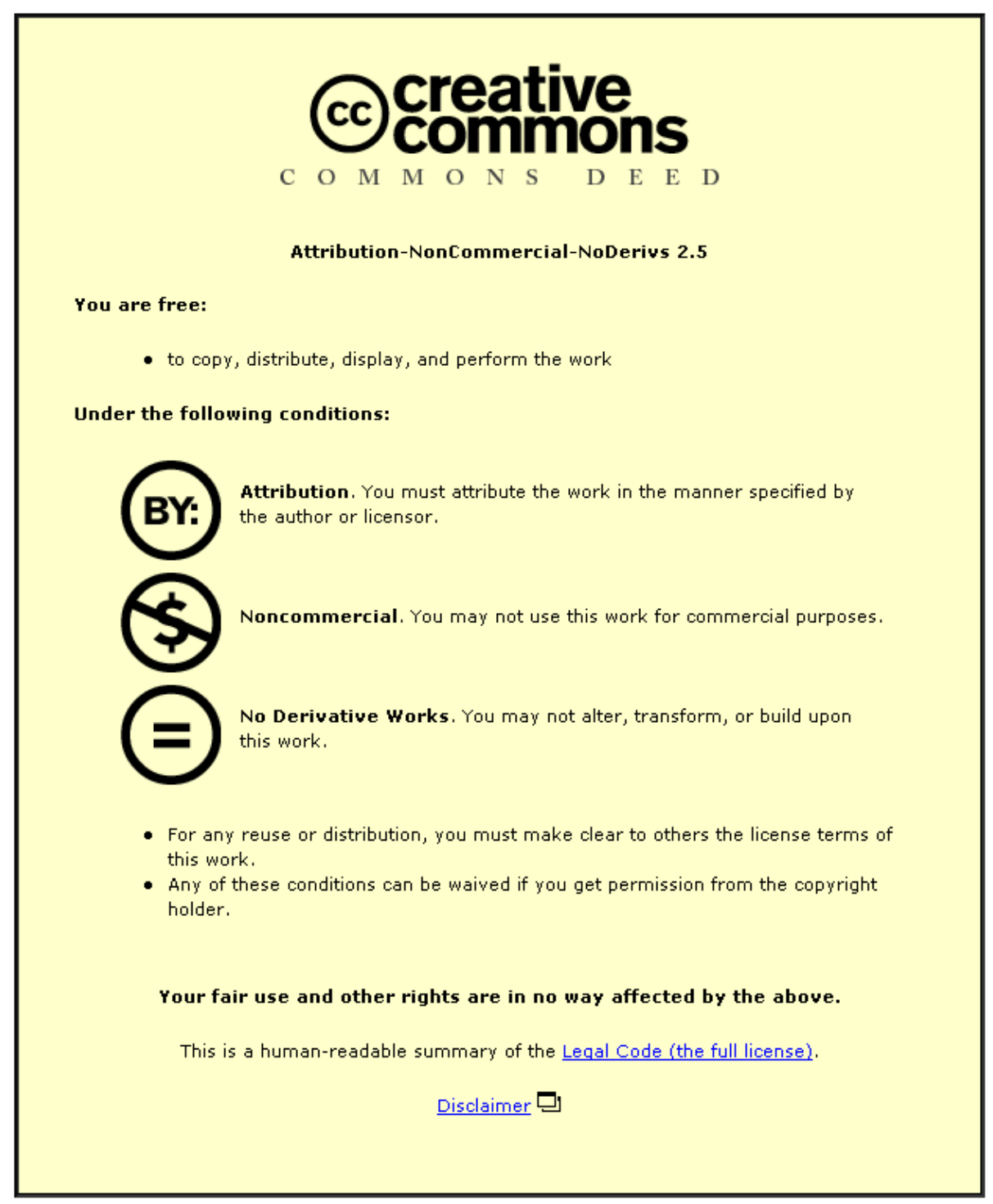

For the full text of this licence, please go to: http://creativecommons.org/licenses/by-nc-nd/2.5/ 
TITLE:

\title{
PREVENTION THROUGH DESIGN: THE EFFECT OF EUROPEAN DIRECTIVES ON CONSTRUCTION WORKPLACE ACCIDENTS ${ }^{1}$
}

\author{
AUTHORS: \\ Name: Ma Dolores \\ Family name: Martínez Aires (M. Aires) \\ Architectural Construction Department. University of Granada \\ E.U. Arquitectura Técnica \\ C/Severo Ochoa s/n \\ 18071 Granada, SPAIN \\ aires@ugr.es \\ +34958246299 \\ Name: Ma Carmen \\ Family name: Rubio Gámez \\ Construction Engineering. Civil Engineering Department. University of Granada \\ E.T.S. de Caminos, Canales y Puertos \\ C/Severo Ochoa s/n \\ 18071 Granada, SPAIN \\ mcrubio@ugr.es \\ TF 958249445 \\ Alistair Gibb \\ Department of Civil and Building Engineering \\ Loughborough University \\ Leicestershire \\ LE11 3TU \\ A.G.Gibb@lboro.ac.uk \\ +44(0)1509 223097
}

\begin{abstract}
Workplace accidents still occur with distressing frequency, particularly in construction. Industrialized countries have become increasingly aware of this situation and have adopted policies to attempt to deal with this issue. Such policies have led to the development of new laws and regulations with a view to improving workplace conditions.

This paper first analyzes policies regarding accident prevention in the European Union, as initially stipulated in the European Framework Directive 89/391/EEC, and more specifically in Directive 92/57/EEC, on the implementation of minimum safety and health requirements at temporary or mobile construction sites, concentrating on prevention through design. Whilst designers previously had some responsibilities for reducing risk under common law provisions in many countries, this directive was the first explicit legislation to enforce particular duties upon them. The adaptation of the provisions in this directive to the national legislation of EU member countries is also studied.

The second section of the paper analyzes the incidence rate of workplace accidents in the construction sector in each country from the year when these regulations came into force until the present time. Based on the evolution of these accident rates, the paper postulates the extent to which European policies have contributed to accident prevention in construction. It is now more than a decade since this legislation has been in force which provides a suitable period for a reflective analysis on it is impact.
\end{abstract}

KEYWORDS: Safety, Construction, Directive 92/57/EEC, European Union

\footnotetext{
${ }^{1}$ This paper presents findings from the first stage of collaborative research between the Department of Civil Engineering at the University of Granada (Spain) and the Civil and Building Engineering Department of Loughborough University (United Kingdom).
} 


\section{Introduction}

The reduction of workplace accidents is an immediate social priority and, consequently, accident prevention and risk management are crucial issues for the construction industry in Europe. First of all, this study analyzed European policies related to accident prevention and their contribution to the improvement of work conditions. The effect of such policies is directly related to the reduction or increase of accidents at construction sites. There was also the need to study the perceptions of the effectiveness of these regulations in each member state (as measured by official organisms and other organizations working in this area), and the obstacles encountered when they were initially implemented. The first phase of this research investigated the following:

- milestones of Directive 92/57/EEC on the implementation of minimum safety and health requirements at temporary or mobile construction sites;

- transposition of this directive in the legislation of European Union countries;

- evolution of the incidence rates of construction workplace accidents from the date when the EU regulations first went into force until the present time; and,

- analysis of the effect of EU risk management and accident prevention policies at construction sites.

\section{Frame of reference}

The construction industry is a strategic sector for the economic development of EU countries making a very significant contribution to the gross national product (GNP). According to Euroconstruct (2006), this contribution amounts to $11.9 \%$ of the GNP in EU1 $5^{2}$ countries and also stimulates the demand in many other areas of the economy. In EU15 countries, the construction sector, which includes building companies, public works, demolition and maintenance, has an annual turnover of more than 900 billion Euros (FIEC, 2007). It also employs approximately $8 \%$ of the total number of workers (AMECO, 2006).

Construction is the principal driving force of employment in many parts of the world and, accordingly, its relatively high rate of work-related accidents, injuries and illnesses is significant. The International Labour Organization (ILO, 2005) provides the following figures:

- at least 60,000 fatal accidents occur each year at construction sites all over the world. This is the equivalent to one death every ten minutes;

- one out of every six fatal workplace accidents takes place at a construction site;

- in industrialized countries, $25 \%-40 \%$ of all fatal workplace accidents occur at construction sites;

- in certain countries $30 \%$ of construction workers suffer backaches, pains, and muscular-skeletal problems; and

- according to the fourth European survey of work conditions, $35 \%$ of all construction workers affirm that their work entails a health risk (OSHA, 2007).

The Fig. 1 shows how the standardized incidence rate of work place accidents for the building sector is the highest of the industrial sector.

\footnotetext{
2 In 1951 the European Coal and Steel Community (ECSC) was constituted, being the founding countries: Belgium, West Germany, France, Italy, Luxembourg and the Netherlands. Other countries have been incorporated at different times: Britain, Ireland and Denmark (1973), Greece (1981), Spain and Portugal (1986), Austria, Sweden and Finland (1995). All these countries form the so-called 'Europe of Fifteen', EU15. In May 2004 Estonia, Latvia, Lithuania, Poland, Czech Republic, Hungary, Slovakia, Slovenia, Malta and Cyprus were incorporated (EU25) and in January 2007 Romania and Bulgaria joined, creating the current EU27.
} 


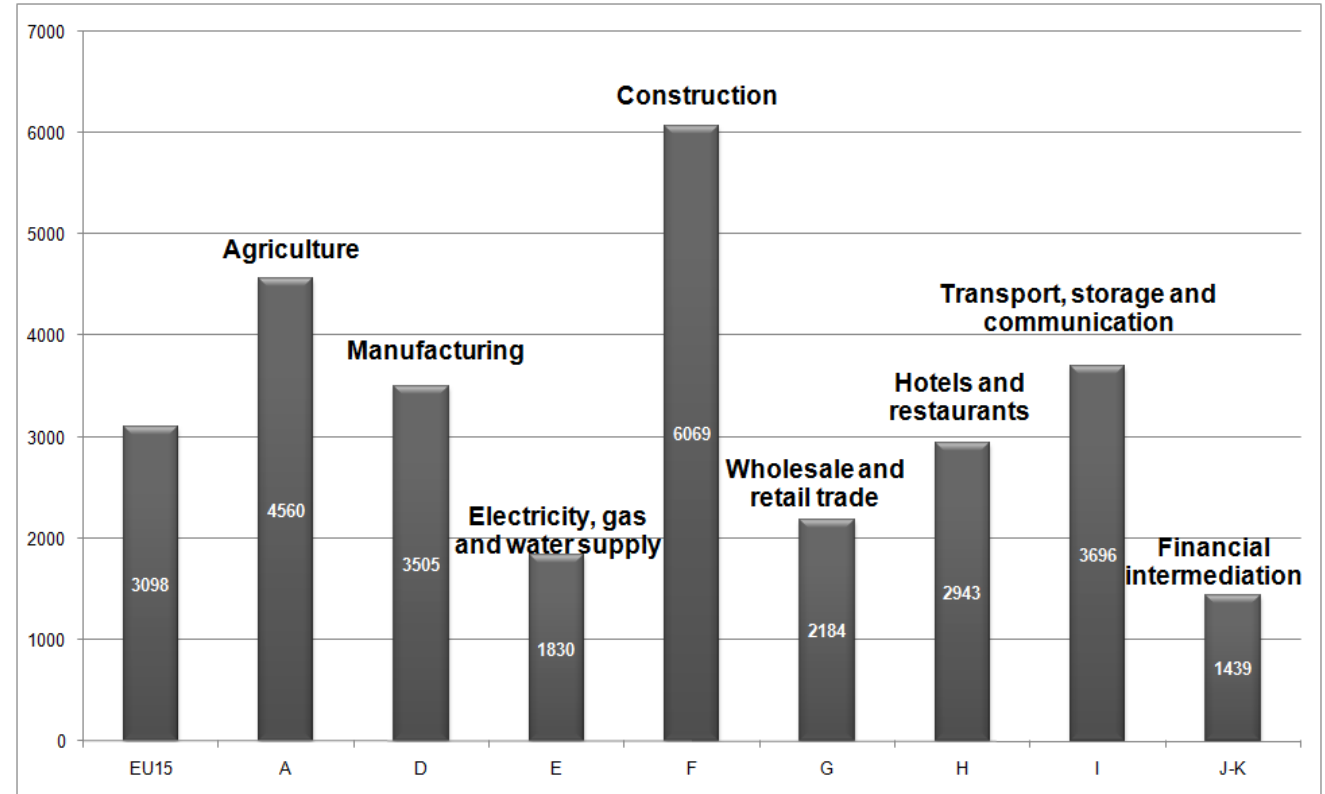

Figure 1. Standardized incidence rate of workplace accidents in terms of economic activity, severity, and sex (rate per 100,000 workers). Loss of more than three days (absence of four days or more) in 2005, European Union (15 countries).

Source: Eurostat

Recent research results show that workplace accidents are caused by a wide range of factors (Gibb et al., 2006; MacDonald, 2006; Abreu Saurin et al., 2006; Whitaker et al., 2003; Huang et al., 2003; Sawacha et al., 1999). The context in which construction work is carried out as well as its characteristics are extremely important, in many cases impeding effective risk management and accident prevention. The construction work environment is by nature dynamic and occupational exposures can vary considerably during the project. Many different companies and trades are simultaneously present at the work site. Other factors to be taken into account are the high percentage of subcontracting, the fact that each building project is unique and also the number of immigrant workers who are unfamiliar with construction materials and methods and who often cannot even speak the local language. Risk in construction environments is also increased because construction personnel work mostly outdoors and must deal with adverse weather conditions. The high worker turnover is also a problem as well as the lack of vocational training and the absence of a safety culture (Lipscomb et al., 2006; Rubio et al., 2005; Chi et al., 2005).

This is the context in which the occupational health and safety policies of the European Union (i.e. Directive 89/391/EEC, and more specifically Directive 92/57/EEC) had to be implemented. Over the course of time, these health and safety requirements were transposed to the legislation of member states, who now must evaluate the effectiveness of these laws, their impact on the number of workplace accidents in the construction industry as well as the improvement of conditions at the construction site.

\section{Methodology}

This research study was carried out in two phases. The first phase analyzed the occupational health and safety requirements applicable to the construction industry (i.e. Directive 92/57/EEC and the adaptation of its provisions in member states). Official statistics regarding workplace accident rates are also analyzed, along with recent research in this area obtained from the following information sources:

- Regulations and requirements

- Official web sites of organizations such as the European Agency for Safety and Health at Work (OSHA) and its links to each EU member state.

- EUR-Lex, the portal to European Union law.

- NATLEX, the database of national labor, social security and related human rights legislation maintained by the ILO's International Labor Standards Department.

- $\mathrm{CIS}$, International Occupational Safety and Health Information Centre.

- Recent research

- Databases such as ScienceDirect and the ISI Web of Knowledge.

- Statistics regarding construction accidents

- Web sites such as Eurostat (European Statistics) and its links to each EU member state. 
The second phase of the project, currently under way, involves working with a panel of experts to assess different national perceptions of the level of implementation and effectiveness of Directive 92/57/EEC as well as the obstacles that have arisen in its enforcement. This evaluation is based on data from a questionnaire given to different entities and organizations directly affected by the provisions of the EU Directive.

\section{Occupational health and safety regulations for the construction industry in the European Union} Because of the rising number of workplace accidents, the European Parliament and/or the Council of the European Union developed a working strategy based on the elaboration of legislative instruments known as Directives. These provide a framework and require member states to achieve a particular result although the precise details of legislative implementation are left to national governments.

European Union legislation concerning occupational health and safety can be found in Framework Directive 89/391/EEC, which introduces provisions and guidelines for the safety and health of workers at the workplace and the duties, responsibilities, and obligations of workers and employers. These basic provisions are further developed in nineteen other directives, which comprise a modern and extensive body of legislation.

The objective of Directive 89/391/EEC, adopted in 1989, is to encourage and enhance the protection of workers through measures concerning the prevention of work-related risks, the protection of safety and health, the elimination of risk and accident factors and also the informing, consultation, balanced participation and training of workers. This directive established the responsibilities and obligations of employers (risk assessment, creation of protection and prevention services, etc.) and the duties of workers (carrying out instructions, correct use of equipment and machinery). The directive applies to both public and private activity sectors, except for those with very specific risks, such as the armed forces or the police.

The implementation of this directive repealed the regulations that were in force in each of the member states. Adopting this directive required considerable effort from national governments, who were obliged to draw up, enact and enforce new laws and regulations in order to comply with the new EU provisions and guidelines. In the first item of article 18, Final Provisions, Framework Directive 89/391/EEC states that Member States shall bring into force the laws, regulations and administrative provisions necessary to comply with this Directive by 31 December 1992". However, very few of the fifteen EU countries actually managed to meet this deadline (Table 1), which shows that the adaptation and transposition process was extremely complex.

\begin{tabular}{|l|l|}
\hline \multicolumn{1}{|c|}{ COUNTRY } & $\begin{array}{c}\text { DATE of entry into } \\
\text { force }\end{array}$ \\
\hline PORTUGAL & 1991 \\
\hline SWEDEN & 1992 \\
\hline FRANCE & 1992 \\
\hline IRELAND & 1993 \\
\hline UNITED KINGDOM & 1993 \\
\hline ITALY & 1994 \\
\hline NETHERLANDS & 1994 \\
\hline LUXEMBOURG & 1994 \\
\hline AUSTRIA & 1995 \\
\hline SPAIN & 1996 \\
\hline GREECE & 1996 \\
\hline GERMANY & 1996 \\
\hline BELGIUM & 1996 \\
\hline DENMARK & 1997 \\
\hline FINLAND & 2002 \\
\hline
\end{tabular}

Table 1. Date when EU15 countries adopted Directive 89/391/EEC within their respective national contexts. 
Regarding safety regulations specific to construction work, Council Directive 92/57/EEC of June 1992 is the eighth individual directive referred to in Article 16 (1) of Directive 89/391/EEC. It establishes minimum safety and health requirements that should be applied to building or civil engineering works at temporary or mobile construction sites.

\section{Summary of Council Directive 92/57/EEC of 24 June 1992 on the implementation of minimum safety} and health requirements at temporary or mobile work sites Source: Adapted from SCADPlus (2007)

This Directive aims to promote better working conditions in this sector of activity ${ }^{3}$ which expose workers to particularly high risks. It requires safety and health considerations to be made during the design and organization of projects. It also provides for the establishment of a chain of responsibility, linking all the players involved, in order to prevent risks. These ideas are further developed in 15 important articles and 4 annexes.

Appointment of coordinators ${ }^{4}$ - Safety and health plan - Prior notice

The client or project supervisor shall appoint one or more coordinators for safety and health matters for any construction site on which more than one contractor is present. He shall ensure that, prior to the setting up of a site, a safety and health plan is drawn up. For construction sites where work is scheduled to last longer than 30 working days and on which more than 20 workers are occupied simultaneously, or on which the volume of work is scheduled to exceed 500 persondays, the client or the project supervisor shall communicate a prior notice.

\section{Project Preparation Stage}

During the project preparation stage, when deciding upon architectural and/or organizational aspects and when estimating the period required for completing the various items or stages of work, the project supervisor (or where appropriate the client) shall take account of the general principles of prevention concerning safety and health referred to in the Directive (89/391/EEC) and of any safety plans. The coordinators shall coordinate implementation of the general principles of prevention, draw up a safety and health plan and prepare a file containing relevant safety and health information to be taken into account during any subsequent works.

\section{Project Execution Stage}

During the project execution stage, the coordinators on the site shall:

- $\quad$ ensure that employers and self-employed persons apply the principles of prevention and follow the safety and health plan where required;

- $\quad$ organize cooperation between employers in respect of safety and health matters;

- coordinate arrangements to check that working procedures are being implemented correctly; and

- $\quad$ take steps necessary to ensure that only authorized persons are allowed onto the site.

\section{Responsibilities of clients, project supervisors and employers}

Even where a coordinator has been appointed, this does not relieve the client or project supervisor of responsibilities in respect of safety and health matters.

\section{Obligations of employers}

Employers are obliged to comply with the minimum safety and health requirements applicable to construction sites. These cover such aspects as energy distribution installations, emergency routes and exits, ventilation, temperature, traffic routes - danger areas, sanitary equipment, etc. They must also take into account directions from the coordinator for safety and health matters.

\section{Obligations of self-employed persons}

All self-employed persons shall comply, mutatis mutandis, with the principles and certain provisions of the Directives concerning the use of work equipment and personal protective equipment, in order to preserve the safety and health of all persons present on the site.

\section{Provision of information to workers, worker consultation, worker participation}

Workers and/or their representatives shall be informed of all the measures to be taken concerning their safety and health on the construction site. The information must be comprehensible to the workers concerned.

Consultation and participation of workers and/or of their representatives shall take place, ensuring,, whenever necessary proper coordination between workers and/or workers' representatives, having regard to the degree of risk and the size of the work site.

3 The Directive applies to all sectors of activity, both public and private (industrial, agricultural, commercial, administrative, service, educational, cultural, leisure, etc.). It does not apply to drilling and extraction in the extractive industries, nor for certain specific public service activities, such as the armed forces or the police, or to certain specific activities in the civil protection services.

${ }^{4}$ Definition of terms: In this Directive:- "temporary or mobile construction sites" means any construction site at which building or civil engineering works are carried out;- "client" means any natural or legal person for whom a project is carried out;- "project supervisor" means any natural or legal person responsible for the design and/or execution and/or supervision of the execution of a project, acting on behalf of the client;- "self-employed person" means any person whose professional activity contributes to the completion of a project;- "coordinator for safety and health matters" at the project preparation stage and at the project execution stage means any natural or legal person entrusted by the client and/or project supervisor, during preparation of the project design and during execution of the project, with performing the duties referred to below (see "Preparation of the project" and "Execution of the project"). 
The authors found that certain countries were able to adapt national occupational health and safety regulations to existing contexts in the construction sector by implementing Directive 92/67/EEC and correcting omissions in this directive, which is now more than sixteen years old. The study has some limitations because the information in countries such as Slovakia, the Czech Republic, Cyprus, Slovenia, and Hungary only appeared in the national languages and was not available in English.

In reference to candidate countries or states in which adhesion negotiations at the time of the study were underway, the national laws in each country before joining the EU in 2004 had to mention EEC Directives, namely, Framework Directive 89/391/EEC and Directive 92/57EEC, which specifically develops its basic premises. This research observed that recent EU member countries have preferred to simply make a literal translation of these directives rather than adapting them to their respective national contexts. Whilst this practice may be expedient, there is a suggestion that such action is less likely to result in meaningful legislation that is enforced in the countries concerned.

\begin{tabular}{|c|c|c|c|}
\hline Country & $\begin{array}{l}\text { Date of } \\
\text { national } \\
\text { legislation }\end{array}$ & National Law & Amending text(s) \\
\hline DENMARK & 1994 & \begin{tabular}{|l} 
Ministry of Labour Order No. 1017 of 15 \\
December 1993 on the Conditions at \\
Construction Sites and Similar Places of Work. \\
\end{tabular} & $\begin{array}{l}\text { Royal Decree of } 25 \text { January } 2001 \text { on temporary or } \\
\text { mobile. }\end{array}$ \\
\hline FRANCE & 1994 & $\begin{array}{l}\text { Law No. 93-1418 of } 31 \text { December } 1993 \text { amending } \\
\text { provisions of Labor Code applicable to building } \\
\text { and civil engineering to ensure security and } \\
\text { protect the health of workers. }\end{array}$ & $\begin{array}{l}\text { Decree No. 2003-68 of } 24 \text { January } 2003 . \\
\text { Decree No. } 94-1159 \text { of } 26 \text { December } 1994 .\end{array}$ \\
\hline FINLAND & 1994 & $\begin{array}{l}\text { Council of State Decision on safety of construction } \\
\text { work (629/1994) }\end{array}$ & $\begin{array}{l}\text { Council of State Ordinance (No. } 426 \text { of 2004) to } \\
\text { amend Council of State Decision (No. } 629 \text { of } \\
\text { 1994) respecting safety in construction work. } \\
\text { Ordinance No. } 702 \text { of } 2006 \text { to amend Council of } \\
\text { State Decision (No. } 629 \text { of 1994) on safety in } \\
\text { construction work. }\end{array}$ \\
\hline NETHERLANDS & 1994 & $\begin{array}{l}\text { Decree of } 3 \text { August } 1994 \text {. Regulations regarding } \\
\text { work at temporary and mobile construction } \\
\text { sites }\end{array}$ & \\
\hline LUXEMBOURG & 1994 & $\begin{array}{l}\text { Law No. A-94/1104 h/ RGD Grand-Ducal } \\
\text { Regulation of November 4, 1994. Minimum } \\
\text { Safety and Health requirements to be observed } \\
\text { at temporary or mobile construction sites. }\end{array}$ & $\begin{array}{l}\text { Grand Ducal Regulation of } 29 \text { October } 2004 \\
\text { concerning the minimum safety and health to } \\
\text { implement at temporary or mobile. } \\
\text { Grand Ducal Regulation of } 27 \text { June } 2008 \\
\text { concerning the minimum safety and health to } \\
\text { implement at temporary or mobile. }\end{array}$ \\
\hline UNITED KINGDOM & 1995 & $\begin{array}{l}\text { S.I. 1994/3140, the Construction (Design and } \\
\text { Management) Regulations of } 1994\end{array}$ & \begin{tabular}{|l} 
The Construction (Design \& Management) \\
Regulations 2007 (CDM 2007)
\end{tabular} \\
\hline SWEDEN & 1995 & $\begin{array}{l}\text { AFS 1994: 52, published on } 20 \text { February } 1995 \\
\text { and enacted on } 1 \text { April } 1995\end{array}$ & $\begin{array}{l}\text { Provisions of the Swedish National Board of } \\
\text { Occupational Safety and Health on Building } \\
\text { and Civil Engineering Work. No. } 3 \text { of } 1999 .\end{array}$ \\
\hline PORTUGAL & 1995 & $\begin{array}{l}\text { Decree-Law No. 155/95 of } 1 \text { July } 1995 \\
\text { implementing Directive 92/57/EEC. }\end{array}$ & $\begin{array}{l}\text { Decree-law number } 273 / 2003 \text { on review of the } \\
\text { regulation of the conditions of safety and health } \\
\text { at temporary or mobile construction sites. }\end{array}$ \\
\hline IRELAND & 1995 & $\begin{array}{l}\text { S.I. No. } 138 \text { of } 1995 . \text { Safety, Health and Welfare } \\
\text { at work (construction). }\end{array}$ & $\begin{array}{l}\text { Safety, Health and Welfare at Work (Construction) } \\
\text { (Amendment) Regulations } 2003 \text { (S.I. No. } 277 \\
\text { of 2003). } \\
\text { Safety, Health and Welfare at Work (Construction) } \\
\quad \text { Regulations, } 2001 .\end{array}$ \\
\hline ITALY & 1996 & \begin{tabular}{|l} 
Legislative Decree No. 494 of 14 August 1996 \\
implementing Directive 92/57/EEC.
\end{tabular} & \\
\hline GREECE & 1996 & $\begin{array}{l}\text { Presidential Decree No. } 305 \text { of } 29 \text { August } 1996 \text { on } \\
\text { the implementation of the EEC Directive No. } \\
\text { 92/57. }\end{array}$ & \\
\hline
\end{tabular}


Ma D. M. AIRES, Ma C. RUBIO GAMEZ, ALISTAIR GIBB

\begin{tabular}{|c|c|c|c|}
\hline SPAIN & 1997 & $\begin{array}{l}\text { Royal Decree } 1627 / 1997 \text {. Minimum provisions for } \\
\text { health and safety at building sites }\end{array}$ & \\
\hline GERMANY & 1998 & $\begin{array}{l}\text { Construction Site Order (Baustellenverordnung) } \\
18 \text { June 1998, Part I, No.35. }\end{array}$ & $\begin{array}{l}\text { Ordinance on compulsory conditions of } \\
\text { employment in the construction industry. } \\
\text { Bundesgesetzblatt, Part I, 1999-08-31, No. 44, } \\
\text { pp. 1891-1902. } \\
\text { Second Decree on mandatory working conditions } \\
\text { in the construction industry. Bundesgesetzblatt, } \\
\text { 2000-08-22, No. 39, pp. 1290-1299. } \\
\text { Third Ordinance on obligatory conditions for work } \\
\text { in the construction industry. Bundesgesetzblatt, } \\
\text { Part I, 2002-08-27, No. 60, pp. 3372-3383, } \\
\text { ISSN: 03411095. }\end{array}$ \\
\hline AUSTRIA & 1999 & $\begin{array}{l}\text { Act on the Coordination of Construction Work. } \\
\text { No.37. } \\
\text { Bundesgesetzblatt, Part I, 1999, No. } 37 .\end{array}$ & \\
\hline BELGIUM & 1999 & $\begin{array}{l}\text { Royal Order of } 3 \text { May } 1999 \text { concerning temporary } \\
\text { or mobile construction sites. }\end{array}$ & $\begin{array}{l}\text { Royal Decree of } 19 \text { December } 2001 \text { amending the } \\
\text { Royal Decree of } 25 \text { January } 2001 \text { on temporary } \\
\text { or mobile, as regards the training of } \\
\text { coordinators safety and health. } \\
\text { Royal Decree of } 25 \text { January } 2001 \text { on temporary or } \\
\text { mobile. } \\
\text { Royal Decree of } 4 \text { August } 1999 \text { amending the } \\
\text { royal decree of } 3 \text { May } 1999 \text { on temporary or } \\
\text { mobile. }\end{array}$ \\
\hline
\end{tabular}

Table 2. Date when EU15 countries adopted Directive 92/57/EEC in their national legislation, and amending texts.

Regarding the adoption date of Directive 92/57EEC, Article 14 states that member states shall bring into force the laws, regulations and administrative provisions necessary to comply with this Directive by 31 December 1993 at the latest (Table 2). However, as also occurred with Directive 89/391/EEC, most of the member states, with the exception of Denmark, were unable to meet this deadline.

Member states had to communicate to the European Commission the texts of the provisions of national law which they had already adopted or would adopt in the field governed by these Directives. In reference to Directive 92/57/EEC (temporary and mobile construction sites), the OSHA report (OSHA, 2004) affirms that, by 2004 , the majority of the member states had communicated to the European Commission the text of the basic provisions, except for the Czech Republic and Malta. However, no analysis has been made of these texts. Given the absence of research on the contents of national laws, which are adaptations of Directive 92/57/EEC, one of the objectives of this study was to fill this gap and see how each member state has implemented this directive. The results can be summarized as follows (Table 3 ). 


\begin{tabular}{|c|c|c|c|c|}
\hline & $\begin{array}{l}\text { Structure } \\
\text { of the law }\end{array}$ & Safety and Health Plan & $\begin{array}{l}\text { Profile of the Coordinator for safety and } \\
\text { health matters at the project preparation } \\
\text { stage. Minimal training required }\end{array}$ & $\begin{array}{l}\text { Profile of the Coordinator at the construction } \\
\text { stage }\end{array}$ \\
\hline $\begin{array}{l}\text { Directive } \\
\text { 92/57/EEC }\end{array}$ & $\begin{array}{l}15 \text { articles and } 4 \\
\text { annexes }\end{array}$ & $\begin{array}{l}\text { The client or the project supervisor shall ensure } \\
\text { that prior to the setting up of a construction site } \\
\text { a safety and health plan setting out the rules } \\
\text { applicable to the construction site concerned, } \\
\text { taking into account where necessary the } \\
\text { industrial activities taking place on the site }\end{array}$ & $\begin{array}{l}\text { Coordinator for safety and health matters at } \\
\text { the project preparations stage: means any } \\
\text { natural or legal person entrusted by the client } \\
\text { and/or project supervisor, during preparation of } \\
\text { the project design. }\end{array}$ & $\begin{array}{l}\text { Coordinator for safety and health matters at } \\
\text { the project execution stage: means any } \\
\text { natural or legal person entrusted by the client } \\
\text { and/or project supervisor, during execution of } \\
\text { the project. }\end{array}$ \\
\hline Austria & 12 articles & $\begin{array}{l}\text { Health and Safety Plan is not defined in legislation. } \\
\text { Health and Safety File for subsequent maintenance } \\
\text { work: when the construction is finished the file } \\
\text { has to be handed over to the owner. }\end{array}$ & $\begin{array}{l}\text { Coordinator appointed by owner or Project manager. } \\
\text { No specific requirements- sufficient experience } \\
\text { and knowledge }\end{array}$ & $\begin{array}{l}\text { He has to be an experienced person with an } \\
\text { adequate education. There is no specific training } \\
\text { legally imposed. }\end{array}$ \\
\hline Belgium & $\begin{array}{l}71 \text { articles and } 5 \\
\text { annexes }\end{array}$ & $\begin{array}{l}\text { The client shall ensure that prior to the setting up of } \\
\text { a construction site a Safety and Health Plan. } \\
\text { Define the daily coordination and maintenance of the } \\
\text { dossier. }\end{array}$ & $\begin{array}{l}\text { Coordinator appointed by owner. } \\
3 \text { levels (Project size) Safety consultant diploma and } \\
\quad \text { experience (duration specified) }\end{array}$ & $\begin{array}{l}\text { The profile of the Coordinator is composed of } 3 \\
\text { parts: a basic degree, experience in function of } \\
\text { the degree and a specific safety Coordination } \\
\text { training or examination. Three different levels are } \\
\text { distinguished for Coordinators within the Belgian } \\
\text { legislation. The duration of the specific training } \\
\text { program for coordinators varies between } 80 \text { and } \\
150 \text { hours and deals with health and safety } \\
\text { topics, as well as with co-ordination topics. } \\
\text { The training can also be replaced by a specific } \\
\text { exam. }\end{array}$ \\
\hline Denmark & $\begin{array}{l}12 \text { articles and } 1 \\
\text { annexes }\end{array}$ & $\begin{array}{l}\text { Safety and health Plan when the construction } \\
\text { period exceeds } 30 \text { days and at least } 20 \text { people } \\
\text { are engaged at the same time or the expected } \\
\text { amount of work exceeds } 500 \text { man-days. }\end{array}$ & $\begin{array}{l}\text { Legislation only imposes Coordination in the } \\
\text { construction phase. }\end{array}$ & $\begin{array}{l}\text { Expertise in construction and with good knowledge } \\
\text { of the different actors. } \\
\text { Practical experience in managing construction sites. } \\
\text { Knowledge of H\&S matters within construction. } \\
\text { Legally basic training as for safety rep's in general, a } \\
37 \text { - hour training course with theoretical and } \\
\text { practical lessons (parts of the Working } \\
\text { Environmental Act, Cooperation in H\&S matters, } \\
\text { risk assessments). } \\
\text { Additional training courses targeted to coordinators } \\
\text { have recently been developed at the } \\
\text { "Contractor's School". }\end{array}$ \\
\hline
\end{tabular}




\begin{tabular}{|c|c|c|c|c|}
\hline Finland & $\begin{array}{l}47 \text { articles and } 2 \\
\text { annexes }\end{array}$ & $\begin{array}{l}\text { The client shall appoint a project supervisor. Before } \\
\text { initiating the construction work, the project } \\
\text { supervisor shall plan how the various tasks and } \\
\text { work phases shall be carried out and scheduled } \\
\text { to ensure that no danger arises from the work to } \\
\text { those working on the site or other persons in the } \\
\text { zone affected by the work. }\end{array}$ & $\begin{array}{l}\text { There are no legally binding safety requirements for } \\
\text { the diploma. }\end{array}$ & $\begin{array}{l}\text { The Coordinator shall have a good knowledge of } \\
\text { conditions at the common workplace. No specific } \\
\text { training is legally imposed. The coordinator must } \\
\text { be a competent person with adequate resources } \\
\text { to do the work. }\end{array}$ \\
\hline France & $\begin{array}{l}\text { Amends } 23 \\
\text { articles of Law } \\
n^{\circ} 76-1106\end{array}$ & $\begin{array}{l}\text { A general Health \& safety coordination Plan, } \\
\text { started at the project design and development } \\
\text { phases and update during the construction } \\
\text { period. }\end{array}$ & $\begin{array}{l}\text { Coordinator or Architect appointed by owner. } \\
.3 \text { levels -length of experience specified but no } \\
\text { specific training requirement. }\end{array}$ & $\begin{array}{l}\text { Same conditions as for the Coordinator at the } \\
\text { preparation stage. }\end{array}$ \\
\hline Germany & $\begin{array}{l}8 \text { articles and } 1 \\
\text { annexes }\end{array}$ & $\begin{array}{l}\text { If prior notice is to be communicated en the case of } \\
\text { a construction site on which employees of several } \\
\text { employers will be occupied, or if work involving } \\
\text { particular risks as specified is performed on a } \\
\text { construction site on which employees of several } \\
\text { employers will be occupied, measures shall be } \\
\text { taken to ensure that prior to the setting up of the } \\
\text { construction site a Safety and Health Plan is } \\
\text { drawn up. }\end{array}$ & $\begin{array}{l}\text { Coordinator appointed by owner. } \\
2 \text { levels (Project complexity) No special trainings - } \\
\text { Prof knowledge, experience and competence. } \\
\text { There is no binding legal imposition concerning the } \\
\text { task profile of a Coordinator at the design stage. } \\
\text { According to the principles of the Professional } \\
\text { Associations of the Constructions Industries, } \\
\text { which is presently substituted by other } \\
\text { regulations, a Coordinator at the design stage } \\
\text { must have sufficient experience in planning and } \\
\text { sufficient knowledge in the field of work } \\
\text { protection. } \\
\text { The minimum requirement for training of a } \\
\text { coordinator is } 32 \text { hours; he must, however, have } \\
\text { additional knowledge in the field of work } \\
\text { protection depending on the type and size of the } \\
\text { design. }\end{array}$ & $\begin{array}{l}\text { There is no binding legal imposition concerning the } \\
\text { task profile of a Coordinator at the construction } \\
\text { stage. According to the principles of the } \\
\text { Professional Associations of the Constructions } \\
\text { Industries, which is presently substituted by } \\
\text { other regulations, a coordinator at the design } \\
\text { stage must have sufficient experience in } \\
\text { planning and sufficient knowledge in the field of } \\
\text { work protection. } \\
\text { The minimum requirement for training of a } \\
\text { coordinator is } 32 \text { hours; he must, however, have } \\
\text { additional knowledge in the field of work } \\
\text { protection depending on the type and size of the } \\
\text { design. }\end{array}$ \\
\hline Greece & $\begin{array}{l}15 \text { articles and } 4 \\
\text { annexes }\end{array}$ & $\begin{array}{l}\text { The Safety and Health Plan will be part of the } \\
\text { documentation presented to obtain permission to } \\
\text { works. This document will be updated during the } \\
\text { development of the work. }\end{array}$ & $\begin{array}{l}\text { Required qualifications of the Project Designer are } \\
\text { sufficient for the required profile of the } \\
\text { Coordinator at the design stage. }\end{array}$ & $\begin{array}{l}\text { Qualifications of the Coordinator for the construction } \\
\text { stage are those required for the supervising } \\
\text { engineer and the safety engineer. }\end{array}$ \\
\hline Ireland & $\begin{array}{l}129 \text { articles and } \\
10 \text { annexes }\end{array}$ & $\begin{array}{l}\text { It shall be the duty of the project supervisor } \\
\text { appointed for the construction stage to develop } \\
\text { before the commencement of the construction } \\
\text { work the Safety and Health Plan for the } \\
\text { construction site. This document will be updated }\end{array}$ & $\begin{array}{l}\text { Project supervisor appointed by owner. } \\
\text { Competent but no specified requirements. } \\
\text { There are no specified legal requirements for the } \\
\text { Diploma or qualifications. The PSDS must be } \\
\text { competent which implies experience, }\end{array}$ & $\begin{array}{l}\text { No specific safety and health training requirements } \\
\text { are specified, other than that the appointed } \\
\text { persons or entities are competent to carry out } \\
\text { the duties. }\end{array}$ \\
\hline
\end{tabular}




\begin{tabular}{|c|c|c|c|c|}
\hline & & during the development of the work. & knowledge/training. & \\
\hline Italy & $\begin{array}{l}24 \text { articles and } 5 \\
\text { annexes }\end{array}$ & $\begin{array}{l}\text { The client or the project supervisor shall ensure that } \\
\text { prior to the setting up of a construction site a } \\
\text { Safety and Health Plan. }\end{array}$ & $\begin{array}{l}\text { Coordinator appointed by owner. } \\
\text { Specific skills } \neg \text { training ( } 60 \mathrm{hr} \text { or } 120 \mathrm{hr} \text { ) also min } \\
\text { academic quals. }\end{array}$ & $\begin{array}{l}\text { The requirements of the profile of the Execution } \\
\text { Phase Coordinator is the same as those of the } \\
\text { Design Stage Coordinator. }\end{array}$ \\
\hline Luxembourg & $\begin{array}{l}\text { The same } \\
\text { structure as the } \\
\text { Directive }\end{array}$ & $\begin{array}{l}\text { The client or the Coordinator shall ensure that prior } \\
\text { to the setting up of a construction site a Safety } \\
\text { and Health Plan. } \\
\text { Define the daily coordination containing the useful } \\
\text { safety and health to be taken into account in any } \\
\text { future work. }\end{array}$ & $\begin{array}{l}\text { Coordinator appointed by architect or owner. } \\
\text { The present legislation does not define necessary } \\
\text { competences (diploma, additional training, etc.) } \\
\text { for the coordinators. }\end{array}$ & $\begin{array}{l}\text { The legislation does not define any necessary } \\
\text { foreknowledge (diploma, additional training, } \\
\text { experience, etc.). }\end{array}$ \\
\hline Netherlands & $\begin{array}{l}\text { The same } \\
\text { structure as the } \\
\text { Directive }\end{array}$ & $\begin{array}{l}\text { Health and Safety Plan: not defined in legislation. } \\
\text { Health and Safety File for subsequent maintenance } \\
\text { work. Health and Safety Plan is defined in the } \\
\text { Working Conditions Decree Version valid as from } \\
23 \text { August } 2000 \text {. }\end{array}$ & $\begin{array}{l}\text { Coordinator appointed by architect or owner. } \\
\text { No requirements. }\end{array}$ & No specific training is legally imposed. \\
\hline Portugal & $\begin{array}{l}18 \text { articles and } 3 \\
\text { annexes }\end{array}$ & $\begin{array}{l}\text { The client or the project supervisor shall ensure that } \\
\text { prior to the setting up of a construction site a } \\
\text { Health and Safety Plan. It also defines the } \\
\text { Procedures Sheets and Technical Dossier of } \\
\text { Work. }\end{array}$ & $\begin{array}{l}\text { Coordinator appointed by owner. } \\
\text { Not yet defined in law. }\end{array}$ & The law does not state anything about this issue. \\
\hline Spain & $\begin{array}{l}19 \text { articles and } 4 \\
\text { annexes }\end{array}$ & $\begin{array}{l}\text { Each builder will draw up a Safety and Health Plan. } \\
\text { Define two documents prior to the above: the } \\
\text { study and the study of basic safety and health. }\end{array}$ & $\begin{array}{l}\text { The figure of coordinator is defined in the Work } \\
\text { Environment Act. Coordinator appointed by } \\
\text { owner. } \\
\text { Legally, the only qualification required is a first } \\
\text { degree or a degree in architecture, or a first } \\
\text { degree or a degree in engineering. }\end{array}$ & $\begin{array}{l}\text { Legally, the only required qualification is a first } \\
\text { degree in architecture, architecture degree, first- } \\
\text { degree engineer, or engineer (Building } \\
\text { Arrangement Law, 4th additional provision). }\end{array}$ \\
\hline Sweden & 101 articles & $\begin{array}{l}\text { The client or the project supervisor shall ensure that } \\
\text { prior to the setting up of a construction site a } \\
\text { Safety and Health Plan. }\end{array}$ & $\begin{array}{l}\text { Owner or appointed. Competent but no specific } \\
\text { training. } \\
\text { There is no legal requirement for the diploma. }\end{array}$ & $\begin{array}{l}\text { The Coordinator shall have a good knowledge of } \\
\text { conditions at the common workplace. No specific } \\
\text { training is legally imposed. }\end{array}$ \\
\hline $\begin{array}{l}\text { United } \\
\text { Kingdom }\end{array}$ & $\begin{array}{l}24 \text { articles and } 2 \\
\text { schedule }\end{array}$ & $\begin{array}{l}\text { Every client shall ensure, so far as is reasonably } \\
\text { practicable, that the construction phase of any } \\
\text { project does not start unless a health and safety } \\
\text { plan. It also defines the Health and Safety File }\end{array}$ & $\begin{array}{l}\text { Planning Supervisor appointed by owner. Competent } \\
\text { but no specific training. There are none, other } \\
\text { than that the coordinator must be competent, } \\
\text { which implies education and training. }\end{array}$ & $\begin{array}{l}\text { The Coordinator (the Principal Contractor) must be a } \\
\text { competent contractor with adequate resources to } \\
\text { do the work. }\end{array}$ \\
\hline
\end{tabular}

Table 3. Initial transposition of the Directive 92 in the UE countries

Source: Developed by the authors from ISSA (2001) 
Mạ D. M. AIRES, Mạ C. RUBIO GAMEZ, ALISTAIR GIBB

In addition to the new responsibilities of all the construction stakeholders with regard to eliminating or reducing construction risk prior to the commencement of construction work, the new role of coordinator was created. In the Directive, there are two coordinators, one for design and one for construction. Different countries have addressed these roles in different ways. One of the challenges has been the different ways that each country manages it is construction process in general. For example, the French system tends to appoint a 'Maitre d'ouvre' (Master of the Works) as a project manager for the commissioning client/owner this person is often in the ideal role to fulfill the coordination responsibilities. Alternatively, the UK has a specific design phase coordinator (until recently known as the Planning Supervisor) but the constructionphase coordination role is taken on by the Principal Contractor who is in control of the construction site. Most other EU states have a separate and independent construction-phase coordinator. In most countries, if the coordinator commands the experience requirements for coordinators at preparation stage and execution stage, it could be the same person or organization.

From this analysis and summary of the national versions of the EU regulations, it is possible to observe, that each country has interpreted them in a different way, so:

- Distinction between the coordinator in the project design phase and the coordinator during the project execution phase, in terms of training, tasks, and obligations, and also whether these jobs should be carried out by two different people.

- There are countries that specify different levels of coordination at the design stage, e.g. Belgium, France, and Germany.

- The United Kingdom has effectively novated the role of the construction-phase coordinator to the Principal Contractor.

- The United Kingdom, Italy, Ireland, France, Belgium, and Austria emphasize the training and experience of safety and health coordinators.

- $\quad$ Other countries, such as Austria, make the distinction between construction and public works.

\section{Evaluation of the number of work accidents since the regulations have been in force}

The European Statistics on Accidents at Work (ESAW) methodology considers two main types of indicators on accidents at work: the numbers of accidents and the incidence rates. The incidence rate (I.R. = number of accidents $\times 100$ 000/number of workers in the target population) is more useful than the total number of accidents since it allows comparison of the number of workplace accidents in relation to the number of workers in the sector (frequency).

The comparison of statistics pertaining to different EU countries can be problematic for a number of reasons including:

- There are significant differences in the submission of reports and work accident registration procedures in different EU countries.

- The statistics are based on case-by-case data for accidents at work resulting in more than 3 days absence from work. Criteria for notification and/or registration are also quite different between the member states (Celeste et al.,, 2004):

\begin{tabular}{|l|l|}
\hline $\begin{array}{c}\text { Register all accidents leading to one or } \\
\text { more days of absence from work } \\
\text { (in addition to the day of the accident itself) }\end{array}$ & \multicolumn{1}{|c|}{ Register accidents of more than $\mathbf{3}$} \\
days
\end{tabular}

- It should be pointed out that definition of a workplace accident can vary slightly from one country to another. For example, as expected, a fatal accident at work is defined as an accident which leads to the death of a victim. However, in practice the requirements for linking a death to an industrial incident differ across the EU states, for example:

- where the victim died the same day (Netherlands)

- or within 30 days after the accident (Germany)

- or within 18 months (Spain) 
- or cases where no time limits are laid down (Belgium, Greece, Italy, Luxemburg, Austria, Sweden, Norway and France - except deaths occurred after the recognition of a permanent disability) (Eurostat 2008).

- In a typical fatal accident at work, the death occurs within few days after the day of the accident and the limitation to only the "same day as the accident" involves a significant underestimation.

- Among the differences found, there are two types of declaration procedures in EU countries. Ten countries use insurance-based systems with notification procedures mainly based on accident reports to public or private insurance agencies and others have data from a universal social security system these differences are very likely to affect the validity of the different statistics.

\begin{tabular}{|c|c|c|}
\hline \multicolumn{2}{|c|}{$\begin{array}{l}\text { Insurance Based } \\
\text { Systems }\end{array}$} & $\begin{array}{c}\text { Universal Social Security } \\
\text { System }\end{array}$ \\
\hline Austria & France & Denmark \\
\hline Belgium & Italy & Ireland \\
\hline Greece & Luxembourg & Sweden \\
\hline Germany & Spain & United Kingdom \\
\hline Finland & Portugal & \\
\hline
\end{tabular}

In the Netherlands the data on non-fatal accidents at work are based on a population survey, while the fatal cases refer to cases reported to national authorities (Eurostat, 2008).

- Another point to take into account is the coverage of accidents outside the workplace (including traffic accidents when workers are on their way to work (in itinere accidents) or accidents that occur during work hours (in-mission accidents). Ireland and the United Kingdom are unable to provide information regarding traffic and transport accidents during work. For the Netherlands, the incidence rate for fatalities cannot be calculated before 1997 due to high underestimation. For Luxembourg the number of fatal cases is very low so that the index has little significance. The lack of coverage for this type of accidents has a significant impact on the national numbers of fatalities and for this reason, Eurostat makes an adjustment by excluding road traffic and transport fatalities where possible to calculate the incidence rate of fatal accidents at work for all Member States.

- Finally, the declaration procedures in member states do not cover the same economic activities. A pertinent difference is the type of "Activity" (Economic Sector of Activity) covered. Some databases include all activities, even those of self-employed workers and those employed in the public sector. In contrast, countries like Denmark, France, Ireland and the UK deal with certain sectors separately and, sometimes, different authorities within the same country monitor them.

The harmonization project, the European Statistics on Accidents at Work (ESAW), began in 1990 with the objective of standardizing, on a European scale, the criteria and methodology for the registration of information concerning work accidents. The best standardization solution to the problems listed above would not involve harmonization after the Member States give their data to ESAW, rather the EU should be persuading its states to harmonize their data-collection methods to aid in the comparability of the ESAW data between Member States by Eurostat (e.g. coverage, reporting levels, inclusion/exclusion of specific types of accidents, etc.) (Eurostat, 2001). This will minimize the processes of post harmonization and the data will be more in agreement with reality and allow the comparisons of the results of the Member States.

Table 4 shows the evolution of the incidence rate of workplace accidents which have resulted in the loss of more than three work days in the Construction Sector (F) in EU15 countries. The data used are the official harmonized and standardized figures obtained from Eurostat (2008). 


\begin{tabular}{|c|c|c|c|c|c|c|c|c|c|c|c|c|}
\hline & $\begin{array}{c}\text { Date of } \\
\text { national } \\
\text { legislation } \\
\text { for } \\
92 / 57 / E E C\end{array}$ & 1995 & 1996 & 1997 & 1998 & 1999 & 2000 & 2001 & 2002 & 2003 & 2004 & 2005 \\
\hline EU15 & & 9080 & 8023 & 7963 & 8008 & 7809 & 7548 & 7247 & 6890 & 6492 & 6257 & 6069 \\
\hline Austria & 1999 & 11095 & 7851 & 7010 & 6439 & 6311 & 5499 & 4835 & 5047 & 4522 & 5027 & 4671 \\
\hline Belgium & 1999 & 10488 & 8952 & 8682 & 8658 & 9508 & 7859 & 8131 & 6810 & 6398 & 6151 & 5510 \\
\hline Denmark & 1994 & 3904 & 3729 & 4005 & 3902 & 4062 & 3955 & 3938 & 3847 & 3773 & 3741 & 4264 \\
\hline Finland & 1994 & 6454 & 7172 & 6766 & 7538 & 7074 & 7059 & 6947 & 6584 & 5908 & 6113 & 6549 \\
\hline France & 1994 & 12248 & 11354 & 11872 & 12205 & 11409 & 11407 & 10864 & 10716 & 10066 & 9824 & 9712 \\
\hline Germany & 1998 & 11102 & 9719 & 10021 & 9810 & 9659 & 8893 & 8013 & 7554 & 7029 & 6737 & 6136 \\
\hline Great Britain & 1995 & 2885 & 2552 & 2635 & 2439 & 2367 & 2506 & 2737 & 2635 & 2493 & 2390 & 2382 \\
\hline Greece & 1996 & 8919 & 9061 & 8362 & 6803 & 6247 & 5838 & 5732 & 5203 & 4519 & 3904 & 3112 \\
\hline Ireland & 1995 & 1337 & 1617 & 2188 & 1901 & 2122 & 1630 & 2496 & 2318 & 2725 & 2876 & 2560 \\
\hline Italy & 1996 & 6494 & 6459 & 6289 & 6445 & 6440 & 6450 & 5934 & 5248 & 5097 & 5027 & 4557 \\
\hline Luxembourg & 1994 & 8667 & 10344 & 10486 & 10027 & 10743 & 10942 & 11335 & 11620 & 10812 & 10106 & 8373 \\
\hline Netherlands & 1994 & 2650 & 2603 & 2525 & 2499 & 2721 & 2777 & 2380 & 2427 & 1904 & 2346 & 5836 \\
\hline Portugal & 1995 & 11892 & 12131 & 10375 & 10093 & 8370 & 7048 & 8089 & 6851 & 6821 & 7640 & 7311 \\
\hline Spain & 1997 & 12681 & 13315 & 12870 & 14332 & 14901 & 14807 & 14797 & 14246 & 13651 & 11947 & 11166 \\
\hline Sweden & 1995 & 1237 & 2150 & 1823 & 2247 & 2430 & 2410 & 2491 & 2306 & 2090 & 1837 & 1751 \\
\hline
\end{tabular}

Standardized incidence rate of workplace accidents according to economic activity, severity and age (rate per 100,000 workers). Construction (NACE F). Loss of more than three work days (absence of four days or more)

Source: Eurostat

The statistics in Table 4 show that the variations in the incidence rates between 1995 and 2005 in different countries reflect different tendencies. For example, there are countries such as Austria, Greece, and Portugal, who in this time period have managed to reduce accidents considerably (up to $40 \%$ in some cases), whereas other countries, such as Ireland, Luxembourg, and Sweden, have a higher accident rate than when the provisions in the EU Directive went into force. 


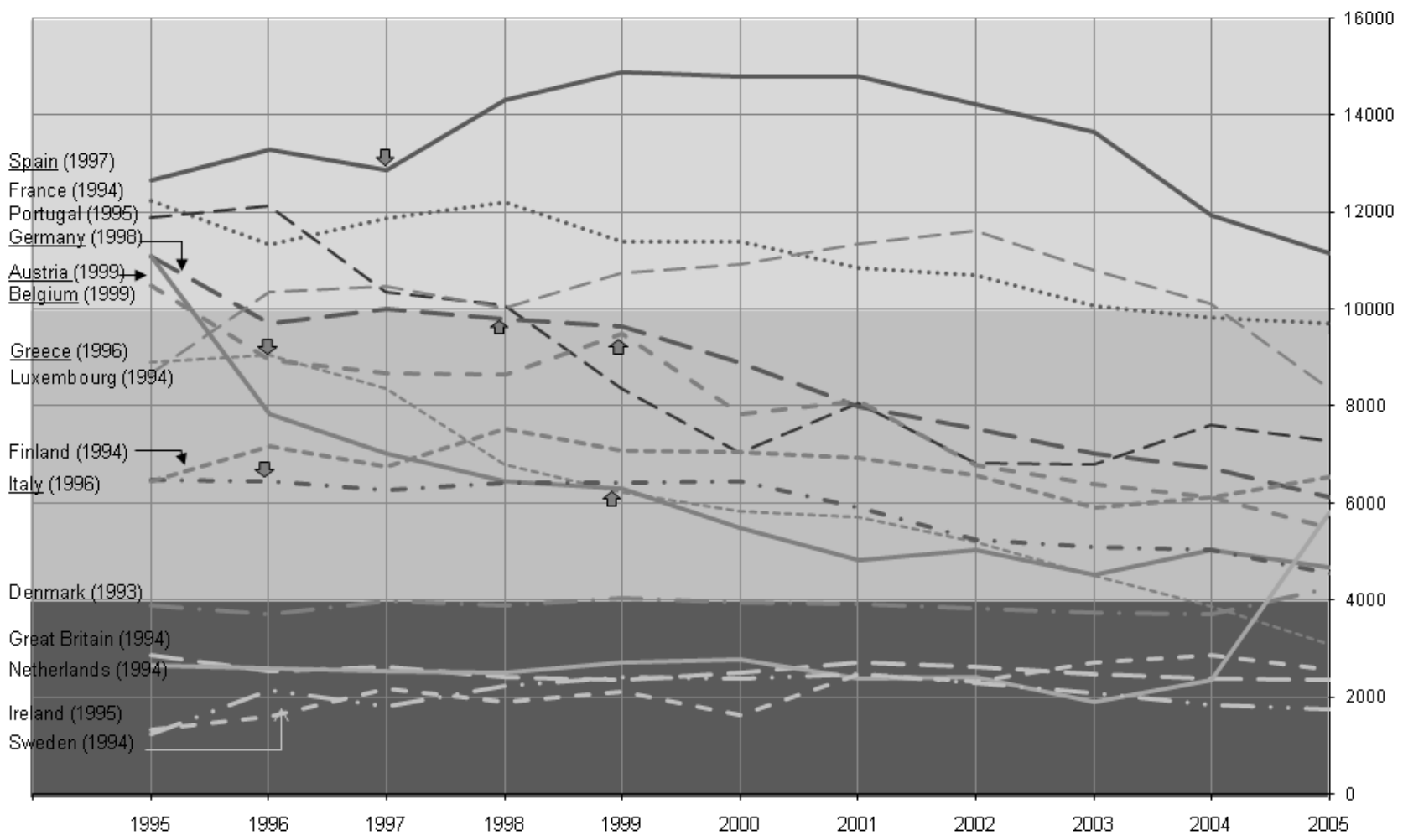

Figure 2

Variation between 1995 and 2005 of the standardized incidence rate of workplace accidents according to economic activity, severity and age (rate per 100, 000 workers). Construction (NACE F). Loss of more than three work days (absence of four days or more)

Source: Eurostat

Figure 2 shows the evolution of the incidence rate from the year when Directive 92/57/EEC went into force until 2004, after which there are, as yet, no official European-wide records. As previously mentioned, despite the harmonization of data carried out by Eurostat, comparisons are difficult. Nevertheless, it was possible to differentiate tendencies that can be put into three groups of countries.

- Countries, such as Denmark, the United Kingdom, Netherlands, Ireland, and Sweden, with a workplace accident rate of less that 4000 and with a stable evolution throughout the time period. All of these countries adopted the provisions of Directive 92/57/EEC in 1996 or before. The case of Ireland is particularly striking because the initial accident rate rose from 1337 in 1995, reaching a total of 2876 in 2004 before decreasing slightly in 2005.

- The most numerous group of countries are those that have an accident rate of between 4000 and 10,000. This group, which includes Greece, Finland, and Italy, is more heterogeneous than the first one insofar as the actual accident rate and its evolution are concerned. All of these countries show an important decrease in their accident rates throughout the time period studied. An exception is Luxembourg, whose accident rate rose from 8667 in 1996 to 10106 in 2004 showing a important decrease in 2005. As mentioned previously, the Luxembourg construction sector is comparatively small and so trends may be less consistent.

- The third group consists of those countries whose accident rate was higher than 10000 in at least some of the years during the time period. Spain, France, Portugal, Germany, Austria, and Belgium belong to this group. With the exception of France and Portugal, all of these countries implemented EU Directive 92/57/EEC later than the countries in the other groups.

Statistics show that Spain is the country that has the highest incidence rate of workplace accidents during this period. It was not until 2003 that the accident rate fell below 14,000. The accident rates in Germany, Austria, Belgium and Greece have clearly become lower after the adoption of the provisions in EU Directive 92/57/EEC. The accident rate in Denmark, the United Kingdom, and the Netherlands remains the same, and does not seem to have been strongly influenced by the directive. In contrast, Portugal and France had a higher number of accidents in certain years during this period, though generally speaking, the accident rate 
Ma D. M. AIRES, Ma C. RUBIO GAMEZ, ALISTAIR GIBB

was reduced. France does not show any reduction until 1998. Between 1995 and 2000, accidents went down in Portugal, but after 2000 there has been no further improvement.

In terms of absolute values, if we analyze the value of the incidence rate of workplace accidents in the year when the EU Directive went into force for each country and the incidence rate in 2005, the results are the following:

\begin{tabular}{|c|c|c|c|c|}
\hline & $\begin{array}{l}\text { Date of national } \\
\text { legislation for } \\
\text { 92/57/EEC }\end{array}$ & $\begin{array}{c}\text { Accident rate } \\
\text { when law } \\
\text { enacted }\end{array}$ & $\begin{array}{l}\text { Accident rate in } \\
2005\end{array}$ & $\begin{array}{l}\% \text { change in } \\
\text { accident rate }\end{array}$ \\
\hline Austria & 1999 & 6311 & 4671 & $-26.0 \%$ \\
\hline Belgium & 1999 & 9508 & 5510 & $-42.0 \%$ \\
\hline Denmark & 1994 & $\begin{array}{c}3904 \\
\text { (refers to 1995) }\end{array}$ & 4264 & $+9.2 \%$ \\
\hline Finland & 1994 & $\begin{array}{c}6454 \\
\text { (refers to 1995) }\end{array}$ & 6549 & $+1.5 \%$ \\
\hline France & 1994 & 12248 & 9712 & $-20.7 \%$ \\
\hline Germany & 1998 & 9810 & 6136 & $-37.5 \%$ \\
\hline $\begin{array}{c}\text { United } \\
\text { Kingdom }\end{array}$ & 1995 & 2885 & 2382 & $-17.4 \%$ \\
\hline Greece & 1996 & 9061 & 3112 & $-65.7 \%$ \\
\hline Ireland & 1995 & 1337 & 2560 & $+91.5 \%$ \\
\hline Italy & 1996 & 6459 & 4557 & $-29.4 \%$ \\
\hline Luxembourg & 1994 & $\begin{array}{c}8667 \\
\text { (refers to1995) }\end{array}$ & 8373 & $-3.4 \%$ \\
\hline Netherlands & 1994 & $\begin{array}{c}2650 \\
\text { (refers to1995) }\end{array}$ & $2346^{*}$ & $-11.5 \%$ \\
\hline Portugal & 1995 & 11892 & 7311 & $-38.5 \%$ \\
\hline Spain & 1997 & 12870 & 11166 & $-13.2 \%$ \\
\hline Sweden & 1995 & 1237 & 1751 & $41.6 \%$ \\
\hline
\end{tabular}

* For year 2005 was taken in 2004's data. The data of 2005 is 5836 and has been labelled by Eurostat as "Break in series".

Table 5

Incidence rate of workplace accident rates (per 100,000 workers) in the year when EU Directive 92/57/EEC was implemented in each country. Construction (NACE F). Loss of more than three work days (absence of four days or more)

Source: Eurostat

As shown in Table 5, 11 of the 15 countries considered have seen a fall in their accident rate since the EU directive was implemented nationally, with and average improvement of $28 \%$, ranging from $66 \%$ to $3.4 \%$. Greece and Belgium shows the best results with a decreasing incident rate of $65,7 \%$ and $42 \%$ respectively. Finland's figures are within 1.5\% and Denmark, Ireland, and Sweden are the countries that have higher accident rates in 2005 than when their national legislation went into force. 


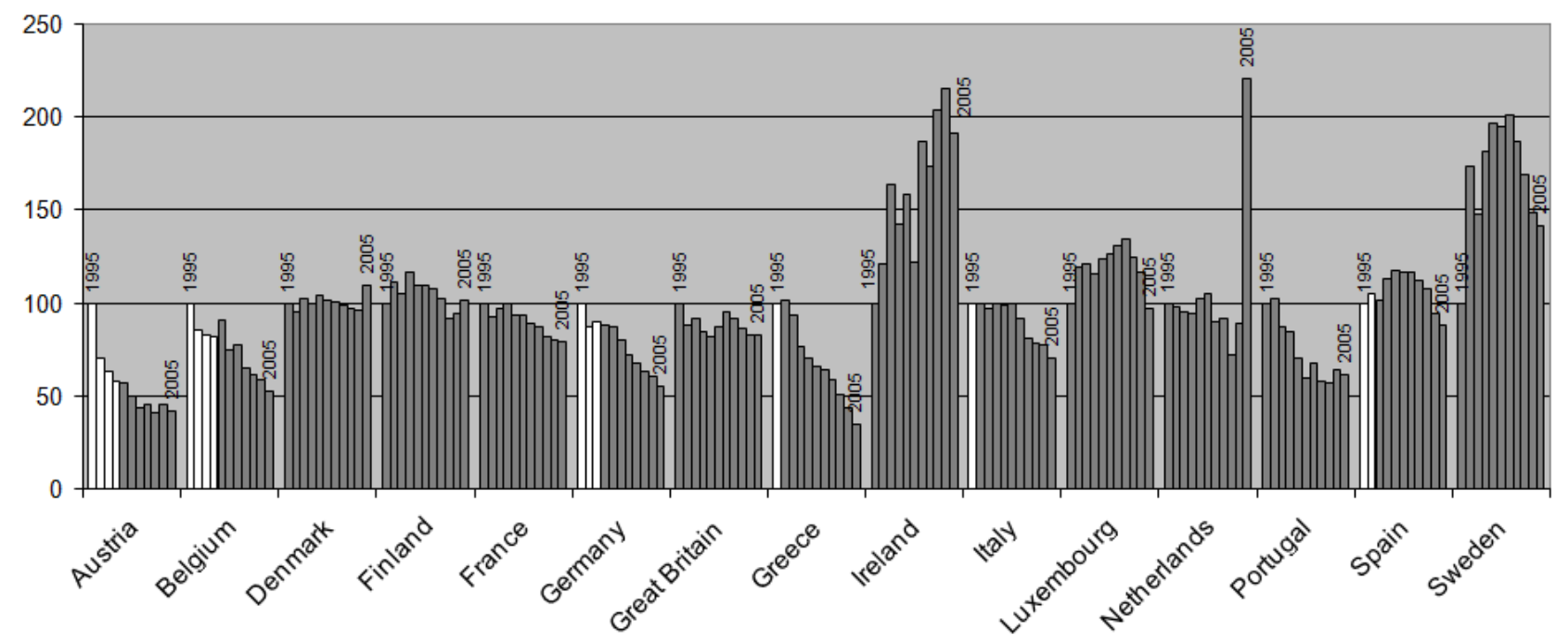

Figure 3

Variation between 1995 and 2005 of the standardized incidence rate of workplace accidents (rate per 100, 000 workers). Construction (NACE F). Loss of more than three work days (absence of four days or more)

Source: Eurostat

Figure 3 draws the evolution of the standardized incidence rate per country since 1995 until 2005 (white columns shows the data before the national law came into force). In this figure the 1995 accident rates of all countries have been normalized to 100 . This clearly demonstrates the relative performance of each particular country in their own context. The Figure highlights a number of peculiar results, in particular Ireland, the Netherlands and Sweden. The authors have sought to establish reasons for these apparent anomalies by contacting the bodies responsible for health and safety in these states.

The Irish Health and Safety Authority commented that there had been some changes over the period in the way that accident data was captured and also that the period had seen a very significant growth in construction activity which often tends to affect accident rates with significant numbers of new, less experienced workers entering the sector. The initial rise in Sweden's incidence rate was caused by changes to their methods of collecting data. New definitions and variables were introduced along with a new form to register occupational illness and accident incidences which requires different information from the older version. The new Swedish registration system which was introduced in 2002, was designed to suit the EU approach. Regardless of this change in the registry, the Swedish authorities argue that, once this settled down, the have seen a reduction in incidence rate since the 2001 peak. The Netherlands changed their methodology on how to collect the number of accidents in 2005 and can no longer compare data from before and after this change. It should also be noted that all these three states are in the 'best performing' category with very low incidence rates. Therefore, a relatively small increase in absolute performance would make a comparatively large swing in the percentage figure.

Regarding the comparison of the incidence rate of workplace accident in different EU countries, the difficulties encountered can be summarized as follows.

There is a lack of official harmonized statistics concerning the incidence rate of workplace accidents before the implementation of EU Directive 92/57/EEC in the various countries. This makes it impossible to study the predominant tendencies (i.e. growth/decline) of the accident rates in the years previous to the adoption of these provisions, and thus limits the study to the time period afterwards.

It is true that statistics can be compared and conclusions from the evolution of the accident rates in each country on an individual basis can be derived. Nevertheless, despite the claimed harmonization of statistical information carried out by Eurostat, comparisons between countries are still not completely reliable. In reference to European work accident statistics, Eurostat admits that there is considerable difficulty in obtaining comparable figures from member states because of the great differences in the systems of 
Ma D. M. AIRES, Mạ C. RUBIO GAMEZ, ALISTAIR GIBB

accident reporting, economic compensation and medical attention for workplace accidents. Such factors may have led to the unavoidable distortion of figures, obtained solely by mathematical procedures without allowing for national differences.

Furthermore, it is necessary to differentiate between the date of the formal enactment of the national law and the date from which it was actually enforced across the sector. Given the complex characteristics of the construction sector, this time period is extremely difficult to determine.

Applying quantitative techniques to issues such as health and safety are fraught with difficulty. Whilst the authors here have sought to establish the affect of the implementation of the EU Directives on construction health and safety performance, there have clearly been other factors and initiatives occurring in EU member states over this period - it is not possible to differentiate conclusively between these different influences. Accident causality is complex (Gibb et al, 2006; Haslam et al, 2003) and difficulties in establishing clear links between such initiatives \& strategies and actual safety performance have been recently discussed by Lehtola et al (2008).

Furthermore, there are other factors that are not directly related to the obligations in the Directives that have not been considered, such as productivity, migrant workers, subcontracting, but which also affect the accident rate. In this sense, it is necessary to consider factors such as training and education (cultural level) of the population in the EU member states. It is relevant that many of the people who work in the construction industry leave school before obtaining a secondary school diploma. If we relate this information to the workplace accident rate, countries in which there are a high number of secondary school dropouts are also those with the highest number of accidents at work (Eurostat, 2006; Euro-lex, 2002). This is the case in Spain and Portugal. There are also likely to be other significant factors affecting the incidence rate - e.g. the volume of work - generally, incidence rates increase as the work volume increases, due to factors such as a large influx of new workers.

Logically, the way that each country has adapted Directive 92/57/EEC to their national legislation has also been different. For example, Belgium and France require the safety and health coordinator to have a certain academic level, training, and experience. Countries, such as Austria, differentiate civil engineering work from building work. These differences in legislative content are also an obstacle when it comes to comparing the situation in different countries.

\section{Conclusions}

All EU countries must comply with the safety and health provisions for the construction sector in EU Directive 92/57/EEC. However, each member state has done this in a different way. Such differences pertain to legislative content, specificity, adaptation, and implementation.

Furthermore, workplace accident rates in EU countries, from the year when the EU provisions went into force up until 2005, have evolved in different ways and reflect a variety of tendencies. Consequently, it is worthwhile to study the adaptation of these safety and health provisions in national laws and even evaluate the level of satisfaction of official bodies and other affected parties. This study will be included in the second phase of this research project.

According to the results obtained, 10 countries experienced a more than $10 \%$ lower workplace accident rate after the Directives' safety and health provisions went into force, three varied less than $10 \%$ and only two had significantly worse rates, although there are some unresolved anomalies with these data. Despite the fact that these regulations are not the only factor to be considered, results show that, since the legislation came into force, the tendency in the European countries is positive and the incidence rate has decreased. However, there is no evidence of the specific success of the TMCS directive itself in terms of national incidence rates because other factors such as "custom and practice", variation of the productivity, and others important events have also occurred. Countries, such as Luxembourg, Ireland, and Sweden, where the accident rate was higher at the end of the time period studied, reflect the need for a more in-depth study of national statistics, the adaptation of the EU provisions, enforcement policy, and implementation in different countries. 
Mạ D. M. AIRES, Mạ C. RUBIO GAMEZ, ALISTAIR GIBB

There is a clear necessity for analyzing the policies of EU15 countries regarding the transposition of the directive. The study should focus on policies that have produced favorable results as well as those that have been rather less successful.

There is also the need to extend this work to the new countries forming the EU27.

\section{References}

Abreu Saurin, T., Buarque, L. (2006). Ergonomic assessment o suspended scaffolds. International Journal of Industrial Ergonomics 36, 229-237

ANECO, 2006. Database Annual macro-economic database. Av ailable from <http://ec.europa.eu/economy finance/indicators/annual macro economic database/ameco en.htm> (Retrieved February 2008).

Celeste J., Elaine A, 2004. A survey on occupational accidents' reporting and registration systems in the European Union. Safety Science. Volume 42, Issue 10, December 2004, 933-960

Chi, C., Chang, T., Ting, H (2005). Accident pattern and prevention measures for fatal occupational falls in the construction industry. Applied Ergonomics 36, 391-400.

Euroconstruct, 2006. Informe anual 2006. Available at: <http://www.euroconstruct.org> (Retrieved October 2006).

Eurostat, 2001. European statistics on accidents at work, 2001. Methodology. DG Employment and Social Affairs - Eurostat. 2001. Doc. ESTAT/E3/HSW/2001/1130. Available at: <http://ec.europa.eu/employment social/news/2002/apr/1130 en.pdf> (Retrieved April 2006).

Eurostat. 2006. Employed in service sector and Occupational status of recent school-leavers. Available at: <http://epp.eurostat.ec.europa.eu> (Retrieved April 2006).

Eurostat, 2008. European Statistics on Accidents at Work (ESAW) and commuting accidents. Eurostat Metadata in SDDS format: Summary Methodology. Available at:

<http://epp.eurostat.ec.europa.eu/cache/ITY SDDS/EN/hsw acc work sm1.htm> (Retrieved October 2008).

Euro-lex, 2002. European benchmarks in education and training: follow-up to the Lisbon European Council. . Available at: <http://eurlex.europa.eu/LexUriServ/LexUriServ.do?uri=CELEX:52002DC0629:EN:HTML> (Retrieved April 2006).

FIEC, 2007. La construcción en Europa, 2007. Cifras clave. Federación Europea de la Industria de la Construcción. Available at: < http://www.fiec.org/main.html> (Retrieved February 2008).

Gibb, A., Haslam, R., Gyi, D., Hide, S., Duff, R., (2006). What causes accidents? Civil Engineering. Vol. $159,46-50$

Haslam, R.A., Hide, S.A., Gibb, A.G.F., Gyi, D.E., Atkinson, S., Pavitt, T.C., Duff, R. \& Suraji, A.(2003) Causal factors in construction accidents, Health and Safety Executive. HSE Report, RR 156, September 2003, 222 pp, ISBN 071762749 7. Available at: <www.hse.gov.uk/research/rrpdf/rr156.pdf> (Retrieved October 2006).

Huang, X., Hinze, J., (2003). Analysis of Construction Worker Fall Accidents. Journal of Construction Engineering and Management. ASCE. 129 n³, June 1, 262-271.

ILO, 2005. Informe sobre Seguridad en el Trabajo, 2005. International Labour Organization. Available at: <http://www.ilo.org/public/spanish/bureau/inf/download/factsheets/pdf/wdshw05.pdf> (Retrieved October 2007). 
Mạ D. M. AIRES, Ma C. RUBIO GAMEZ, ALISTAIR GIBB

ISSA. (2001). Co-ordination of Safety and Health at temporary or mobile construction sites: current statut. Available at: <http://construction.prevention.issa.int/product/publication.htm> (Retrieved June 2007).

Lipscomb, H.J., Glazner, J.E., Bondy, J., Guarini, K., Lezotte, D., (2006). Injuries from slips and trips in construction. Applied Ergonomics 37, 267-274.

Lehtola, MM; van der Molen, H; Lappalainen, J; Hoonakker, PLT; Hsiao, H; Haslam, RA; Hale, AR; Verbeek, JH. (2008). The effectiveness of interventions for preventing injuries in the construction industry - a systematic review. American Journal of Preventative Medicine, Vol 35(1).

MacDonald, G. (2006). Risk perception and construction safety. Civil Engineering. Vol. 159, 51-56.

OSHA, 2004. Latest update on the communication of national measures transposing EU health and safety directives. Available at: <http://osha.europa.eu/legislation/directives/> (Retrieved February 2007).

OSHA, 2007. Fourth European Working Conditions Survey, 2007. Luxembourg: Office for Official Publications of the European Communities, 2007.

Rubio, M.C., Menéndez, A., Rubio, J.C., Martínez, G., (2005). Obligations and Responsibilities of Civil Engineers for the prevention of Labour Risks. Journal of Professional Issues in Engineering Education and Practice. ASCE. January 2005, 70-75.

Sawacha et al., 1999: E. Sawacha, S. Naoum and D. Fong, Factors affecting safety performance on construction sites. International Journal of Project Management 17 (5) (1999), pp. 309-315.

SCADPlus, 2007. Activities of the European Union, Summaries of legislation. Available at: $<$ http://europa.eu/scadplus/leg/en/cha/c11120.htm> (Retrieved February 2007).

Whitaker, S.M., Graves, R.J., Malcolm, J., McCann, P. (2003). Safety with access scaffolds:

Development of a prototype decision aid based on accident analysis. Journal of Safety Research 34, 249-261.

\section{Internet references}

CIS (International Occupational Safety and Health Information Centre). Available at $<$ http://www.ilo.org/public/english/protection/safework/cis/>.

Eurostat (Home Page). Available at: <http://www.europa.eu.int/comm/Eurostat/>.

HASTE (European Health and Safety Database-Home Page). Available at: $<$ http://www.occuphealth.fi/e/eu/haste/>.

ILO (Home Page). Available at <http://www.ilo.org/public/english/index.htm>.

ILO (Statistics Web Site). Available at: <http://www.ilo.org/public/english/bureau/stat/class/acc/index.htm>.

OSHA (European Agency—Home Page). Available at: <http://europe.osha.eu.int/>. 